a memorial to her husband, Dr. Ferdinand V. Hayden, director of the United States Geological and Geographical Survey in the early days of that organisation.

\section{Botanic Gardens in South Africa}

IN Part 17 of the Journal of the Botanical Society of South Africa (1931) is published an excerpt from the report written by Sir Arthur Hill to the Union Government after his tour in South Africa in 1929, which was referred to in NATURE of Feb. 7, 1931, p. 217. The report states that at present, owing to lack of funds, the Director of the Kirstenbosch Botanic Garden is working single-handed and the garden staff is inadequate. This refers to 1929 , and in the present Journal the Gardens have to report a ten per cent reduction of the Government grant which they share in common with other State-aided institutions. On the whole, the moment scarcely seems propitious for the consideration of Sir Arthur Hill's suggestion that South Africa should try to maintain three botanic gardens, with the development of a sub-tropical botanic garden at Durban and a botanic garden with arboretum at Pretoria. It is good to see that the body of supporters for the Kirstenbosch gardens, provided by the Botanical Society of South Africa, continues steadily to grow in numbers. In this same report Sir Arthur Hill presses for the policy of making Table Mountain into a Nature reserve, and it is good to learn that action has now been taken by the Administrator of the Cape Province which gives complete legal protection to the flora and fauna of the Mountain.

\section{Biology and Quantum Theory}

Prof. Niels Bohr, of Copenhagen, has brought together a collection of articles dealing in a rather general way with modern physics, under the title "Atomtheorie und Naturbeschreibung" (Berlin : Julius Springer, 1931. 5.60 gold marks). Reference is made in several of the articles to the question of the relation between the development of quantum theory and the formulation of the fundamental problems of biology. The point of view which is taken is that a consideration of the new ideas and methods of physics, often essentially foreign to ordinary conceptions and experience, may indicate how the discussion of the place of living organisms in our scheme of things should be approached. Prof. Bohr directs attention to the existence of a natural limit to the investigation of life in the inevitable death of an organism which is subjected to a complete physical investigation of its atomic constitution. A recognition of the importance of such matters is perhaps becoming rather general, as we find Dr. P. A. M. Dirac grouping the problem of life with the relativistic formulation of quantum mechanics and the nature of atomic nuclei-as a "more difficult" problem-in the introduction to a paper on quantised singularities in the electromagnetic field, in the Proceedings of the Royal Society for last September, but it can scarcely be irrelevant to refer here also to Samuel Butler's ingenious treatment of a similar topic in "The Book of the Machines", sixty years ago, in "Erewhon".

No. 3253, VoL. 129]

\section{Announcements}

By an order of the Committee of Privy Council, Mr. W. S. Morrison, M.P., has been appointed a member of the Medical Research Council, on the retirement of Major A. G. Church.

Prof. G. Elliot Sмrth, professor of anatomy in University College, London, has been given the honorary degree of M.D. by the Egyptian University, Cairo, on the occasion of its first convocation, held on Feb. 27. Prof. Elliot Smith was at one time professor of anatomy in the Government Medical School, Cairo.

THE third Pedler lecture before the Chemical Society, entitled "The Life and Work of Otto Wallach", will be delivered by Prof. L. Ruzicka, of Zurich, on March 10, at 5.30 P.M. The lecture will be given in the Meeting Hall of the Institution of Mechanical Engineers, Storey's Gate, Westminster, London, S.W.1. Tickets of admission will not be required.

Ar the annual general meeting of the Association of Economic Biologists held on Feb. 26, the following officers were elected: President, Dr. W. B. Brierley; Vice-Presidents, Dr. W. R. Thompson and Mr. A. D. Cotton; Hon. Treasurer, Dr. J. Henderson Smith; Hon. Editors, Dr. W. B. Brierley and Mr. D. Ward Cutler; Hon. Secretaries, Prof. J. W. Munro and Prof. W. Brown.

We have already referred to the sixteenth Annual of the Paris Academy of Sciences (Feb. 6, p. 199), which contains a complete list of members, going back to 1795. The Academy has now issued a small volume containing a list of members and correspon. dants during the period 1666-1793 (Paris : Au Palais de l'Institut, 23, quai de Conti. 1931). This list was compiled by M. A. Lacroix, and gives the dates of birth and death, biographical notes, and posts held by the members.

Applications are invited for the following appointments, on or before the dates mentioned :-An assistant biochemist at the General Hospital, Birmingham - The House Governor, General Hospital, Birmingham (March 12). An aircraft and engine inspector under the Government of India-The High Commissioner for India, General Department, India House, Aldwych, W.C.2 (March 12). A principal of the Sheffield City Training College for Teachers-The Director of Education, Education Office, Sheffield (March 14). An assistant medical secretary of the British Medical Association-The Medical Secretary, British Medical Association, Tavistock Square, W.C.1 (March 14). A professor of education and head of the men's training department of the University College of South Wales and Monmouthshire-The Registrar, University College of South Wales, Cardiff (March 22). A professor of geology in the University of Birmingham--The Secretary, University, Birmingham (April 11). A woman lecturer in biology at Edge Hill Training College, Liverpool-The Principal, Edge Hill Training College, Liverpool (April 19). An assistant bacteriologist in the Central Tuberculosis Laboratory of the King Edward VII. Welsh National Memorial Association-The Bacteriologist, Institute of Preventive Medicine, The Parade, Cardiff. 